\title{
Survey reveals mixed feelings over scientific misconduct
}

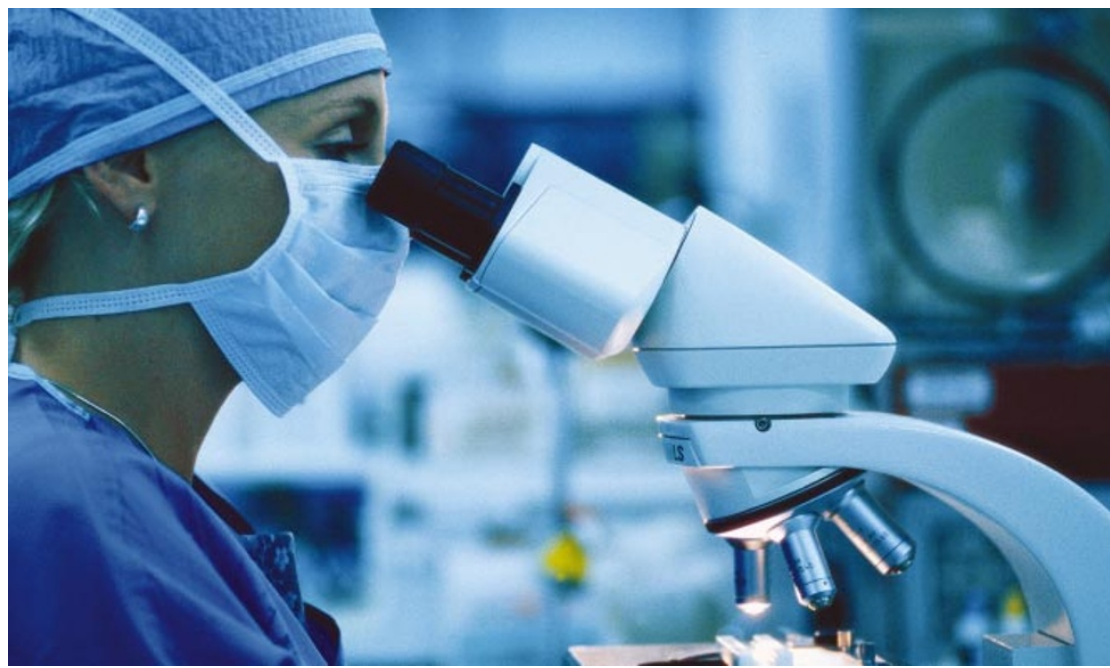

Close scrutiny: two-thirds of scientists have experienced misconduct, and a quarter say it is increasing.

\section{Alison Abbott and Phillip Graf, Munich}

Senior scientists in Germany believe that the increased reporting of research misconduct in the media there is damaging public confidence in science, a survey conducted by Nature has found.

Many acknowledge continuing problems in maintaining good scientific practice and handling allegations of misconduct, particularly in protecting 'whistleblowers' who report misconduct. But two in five said it is "unrealistic" to demand strict adherence to good scientific practice in all circumstances.

The survey, the first to test researchers' opinions after a stream of well-publicized scientific fraud cases in Germany, was conducted among top researchers who serve as reviewers for the DFG, the country's main granting agency. Of 211 researchers contacted in all scientific disciplines, 77 responded.

The DFG has taken a lead in setting standards for scientific practice and ensuring adoption of these and of investigative procedures. Some of its officials support a 'zero tolerance' policy in which all misconduct would be investigated and punished.

But $40 \%$ of respondents say deviations could be accepted in some circumstances. For example, says one, "honorary authorship is justified in some individual cases".

Some two-thirds said that they had had personal experience of misconduct, either directly or indirectly. Most felt that it is a major problem in clinical research $(80 \%)$ and the life sciences (59\%), but only $4 \%$ felt that this is the case in physics and chemistry.

A quarter said they thought that the overall incidence of misconduct is increasing. Eighty-five per cent said that the DFG system is helpful in exposing fraud and protecting the rights of accused scientists. But one-third said that whistleblowers are inadequately protected. Nearly half said that newspaper reports create "an atmosphere of distrust", although a similar proportion believe that journalists play a useful role.

In German universities, researchers can confide their suspicions either to a local ombudsman at their institution, or to one of the DFG's three independent ombudsmen. These can start enquiries, either by the university itself or by a DFG-appointed panel.

DFG ombudsman Hans-Heinrich Trute, a law professor at the University of Hamburg, says he doesn't know why some young scientists apparently do not trust his office, taking their concerns to newspapers instead.

Holger Wormer, a journalist at Munich's leading newspaper the Süddeutsche Zeitung, who has covered several cases, says whistleblowers come to him because they fear that top scientists will protect each other. "It helps that we provide a bit of pressure to break down these old-boy networks," he says.

Trute agrees that more could be done to protect whistleblowers. In Germany, they have to prove that they are victims of malevolent reprisals, he says: the burden of proof should be shifted to those in power to prove they are not, as in the United States. But he sympathizes with scientists who voice doubts about 'zero tolerance' policies. "Sometimes intuition requires a bit of licence," he says.

Peter Hofschneider, emeritus director at the Max Planck Institute for Biochemistry at Martinsried near Munich, who has acted as an informal confidant in several cases, agrees. Young scientists "should not necessarily have their whole research career destroyed because of one misdemeanour", he says.
Europe split over move to loosen stem-cell regulations

Alison Abbott, Munich

The European Union (EU) is set to change its rules on embryonic-stem-cell research.

Under proposals due to be announced this week, researchers would be able to use EU funds to carry out studies of stem cells derived from embryos left over from in vitro fertilization. EU policy is currently unclear, deterring researchers from applying for funding.

The proposal, expected to be made when the European Commission's directorate heads meet on 9 July, will be controversial. Attitudes to embryo research differ widely among EU member states, and negotiators expect a period of intense horse-trading to take place before a vote of $\mathrm{EU}$ member nations in September.

Under EU rules, votes will be distributed according to population, and $29 \%$ of them need to be cast against the proposal for it to be rejected. Germany and Italy each hold $11.5 \%$ of the votes, putting the two countries in key positions.

Both might be expected to block the proposal. Germany only allows work on human embryonic stem cells from lines banked before January 2002, when its policy was set. Italy has no specific law to regulate this kind of research, but there is strong public opposition to it.

Observers say, however, that German negotiators are working behind the scenes to ensure that the proposal is endorsed. This will stop Germany's rules being imposed on other countries. Britain, for example, lets researchers create new stem-cell lines from embryos. With German public opposition to EScell research running high, its delegates will not openly back the proposal. But they may try to get Italy to abstain, or consider doing so themselves.

In contentious $\mathrm{EU}$ votes, the country that holds the rotating presidency currently Italy — traditionally remains neutral. Together with Germany's unwillingness to scupper the proposal, this may persuade Italy to abstain.

"As Italy holds the presidency, it would be irresponsible of it to vote against," says Cinzia Caporale, a bioethicist at the University of Siena and vice-president of the committee of bioethics at the United Nations Educational, Scientific and Cultural Organization. "It would make no difference to the results - Germany would abstain if Italy insists on voting against." 